$\underline{\text { Original Article }}$

\title{
A NEW VALIDATED THIRD ORDER DERIVATIVE SPECTROSCOPIC METHOD FOR SIMULTANEOUS ESTIMATION OF METOPROLOL SUCCINATE AND RAMIPRIL IN TABLET DOSAGE FORM
}

\author{
ALEKHYA B. ${ }^{1}$, M. SINDHUSHA ${ }^{1}$, SORAJ K. RAUL ${ }^{1}$, GOPAL K. PADHY2*
}

1Department of Pharmaceutical Analysis and Quality Assurance, Maharajah's College of Pharmacy, Phool Baugh, Vizianagaram 535002, Andhra Pradesh, India, ${ }^{2}$ School of Pharmacy, Centurion University of Technology and Management, Odisha, India

Email: gopalmedchem@gmail.com

Received: 28 Nov 2019, Revised and Accepted: 24 Mar 2020

\section{ABSTRACT}

Objective: The objective of the present work is to develop and validate a new UV derivative spectrophotometric method for simultaneous estimation of metoprolol succinate and ramipril in methanol: water (50:50v/v).

Methods: "Zero crossing technique" was chosen for quantitative determination. The zero-crossing points (ZCP's) were found to be 209 nm where metoprolol succinate was quantified and $211 \mathrm{~nm}$ where ramipril was quantified. This method was then subjected to accuracy, linearity, sensitivity and reproducibility according to ICH guidelines to ensure and confirm its validity.

Results: The method was found to be obeying Beer's law in the range of $10-50 \mu \mathrm{g} / \mathrm{ml}$ and $5-25 \mu \mathrm{g} / \mathrm{ml}$ for metoprolol succinate and ramipril, respectively. The \% recoveries were observed between the range of 99.2-100.2 for metoprolol succinate and $99.57-99.86$ for ramipril. The intra-day and inter-day results showed reproducibility.

Conclusion: It can be concluded that the developed third-order UV derivative spectroscopic method for the simultaneous determination of metoprolol succinate and ramiprilcan be recommended for routine quantitative analysis.

Keywords: Third order, UV derivative spectroscopy, Metoprolol succinate, Ramipril, Validation, Zero crossing technique

(c) 2020 The Authors. Published by Innovare Academic Sciences Pvt Ltd. This is an open access article under the CC BY license (http://creativecommons.org/licenses/by/4.0/) DOI: http://dx.doi.org/10.22159/ijpps.2020v12i5.36413. Journal homepage: https://innovareacademics.in/journals/index.php/ijpps

\section{INTRODUCTION}

Metoprolol succinate is chemically known as 1-[4-(2-methoxyethyl) phenoxy]-3-(propan-2-ylamino) propan-2-olbutanedioate (fig. 1). It competes with adrenergic neurotransmitters such as catecholamines for binding at $\beta_{1}$-adrenergic receptors in the heart that result in a decrease in heart rate, blood pressure and cardiac output $[1,2]$. Ramipril as shown in (fig. 2) is chemically $(2 S, 3 a S, 6 a S)-1-[(2 S)-2$ [[(2S)-1-ethoxy-1-oxo-4-phenylbutan-2-yl]amino] propanoyl]3,3a,4,5,6,6a-hexahydro-2H-cyclopenta[b]pyrrole-2-carboxylic acid, acts by inhibiting angiotensin-converting enzyme (ACE), thereby lowers the production of angiotensin II and also decreases the breakdown of bradykinin. The decrease in angiotensin II results in lowering total peripheral resistance, widening the blood vessels and hence decreases the blood pressure [3]. Commercial brands of metoprolol succinate and ramipril are available and have been prescribed to the patients who are suffering from myocardial infarction, nephropathy, angina and congestive heart failure [4].

Literature survey revealed that metoprolol succinate and ramipril can be estimated either individually or combinedly by different methods like HPLC [5-7], LC [8], RP-UPLC [9], UV-Spectroscopy [10, 11]. However, simultaneous estimation of these drugs by derivative spectrophotometric method was not reported till date. Hence a third order derivative spectrophotometric method was developed for the simultaneous estimation of these drugs for the first time. The developed UV derivative method was validated according to the ICH guidelines.<smiles>COCCc1ccc(OCC(O)CNC(C)C)cc1</smiles>

Fig.1: Structure of metoprolol succinate

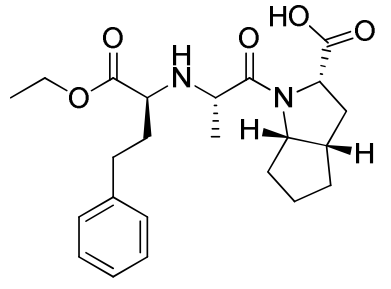

Fig. 2: Structure of ramipril

\section{MATERIALS AND METHODS}

\section{Instrument}

A double beam Agilent Cary UV spectrophotometer with Cary WinUV software (version 5.0.0.999) having a wavelength range of 190-1100 $\mathrm{nm}$ and $1 \mathrm{~cm}$ quartz cell was used for all the spectral studies. A calibrated Shimadzu BL $220 \mathrm{H}$ weighing balance was used for accurate weighing of the chemicals. The statistical calculations were done by using Microsoft excel 2010 version.

\section{Chemicals and reagents}

Analytically pure metoprolol succinate and ramipril from Yarrow chemicals, Mumbai were used. PROLOMET R 50 tablets (in the dose of $50 \mathrm{mg}$ metoprolol succinate and $5 \mathrm{mg}$ ramipril) manufactured by Sun Pharma were procured and used for the investigation.

\section{Preparation of metoprolol succinate standard stock solution}

$25 \mathrm{mg}$ of metoprolol succinate was accurately weighed and transferred into a $25 \mathrm{ml}$ volumetric flask and made up with methanol and water in the ratio of $50: 50 \mathrm{v} / \mathrm{v}$ to get $1000 \mu \mathrm{g} / \mathrm{ml}$ solution. From the above stock solution different working standards in the range of $10-50 \mu \mathrm{g} / \mathrm{ml}$ were prepared. 


\section{Preparation of ramipril standard stock solution}

$25 \mathrm{mg}$ of ramipril was accurately weighed and transferred into a $25 \mathrm{ml}$ volumetric flask and made up with methanol and water in the ratio of 50:50 v/v to get $1000 \mu \mathrm{g} / \mathrm{ml}$ solution. From the above stock solution different working standards in the range of $5-25 \mu \mathrm{g} / \mathrm{ml}$ were prepared.

\section{Method development}

For quantitative estimation, UV derivative spectroscopic method using zero crossing technique was chosen [12]. The working standard solutions containing $30 \mu \mathrm{g} / \mathrm{ml}$ of metoprolol succinate and $15 \mu \mathrm{g} / \mathrm{ml}$ of ramipril were scanned in the wavelength range of 200-
$400 \mathrm{~nm}$ using methanol and water solvent $(50: 50 \mathrm{v} / \mathrm{v})$ as reference in derivative mode at bandwidth of $2 \mathrm{~nm}$ and a scan speed of 400 $\mathrm{nm} / \mathrm{min}$. It showed wavelength maxima at $215 \mathrm{~nm}$ for metoprolol succinate (fig. 3) and $210 \mathrm{~nm}$ for ramipril (fig. 4). The isobestic point was found to be $216 \mathrm{~nm}$ as shown in (fig. 5). The obtained zero order spectra were converted to first order (fig. 6), second order (fig. 7) and third order spectrum (fig. 8).

\section{Method validation}

The developed method was validated in terms of linearity, accuracy, intra-day and inter-day precision studies, detection limit and quantification limit according to ICH guidelines $[13,14]$.

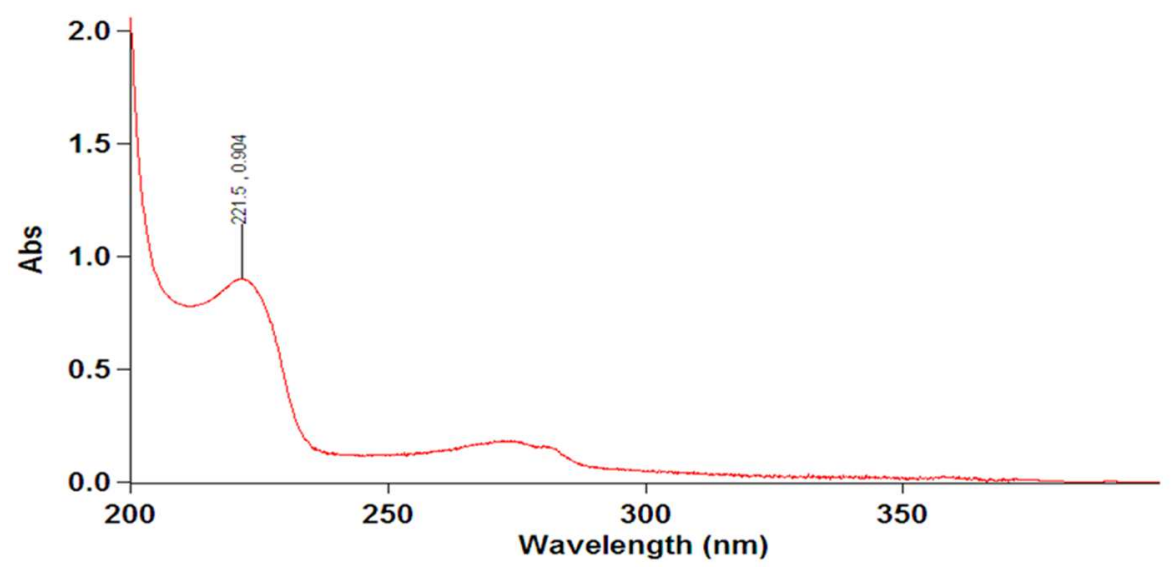

Fig. 3: $\lambda_{\max }$ of metoprolol succinate

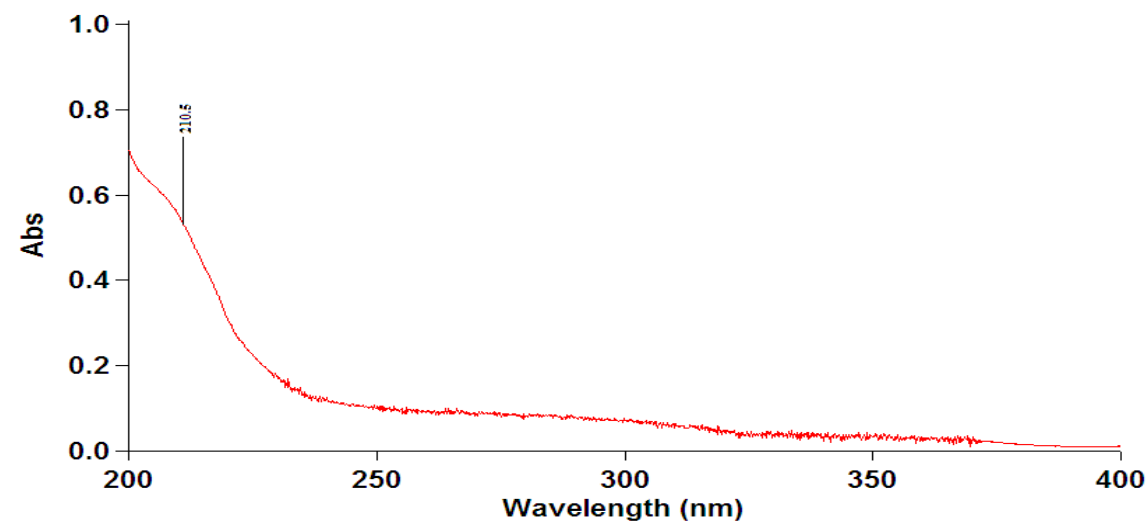

Fig. 4: $\lambda_{\max }$ of ramipril

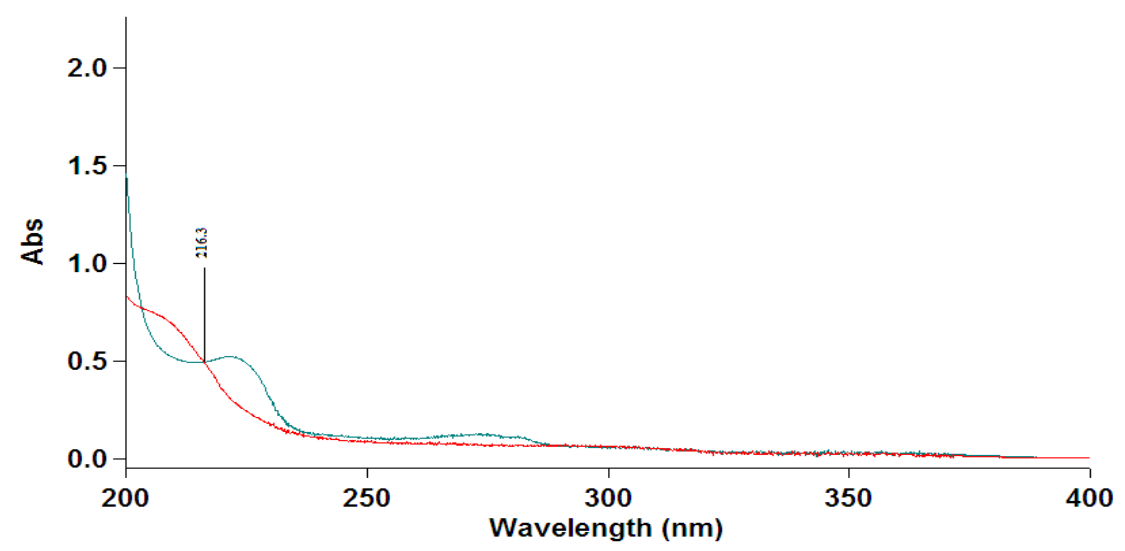

Fig. 5: Zero order spectrum of metoprolol succinate and ramipril 


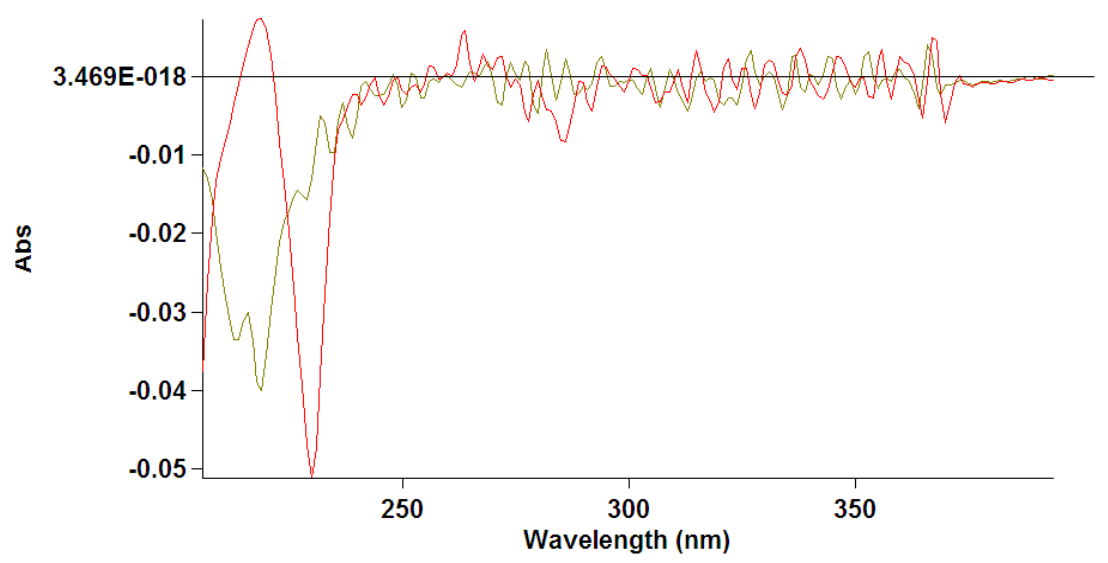

Fig. 6: First order spectrum of metoprolol succinate and ramipril

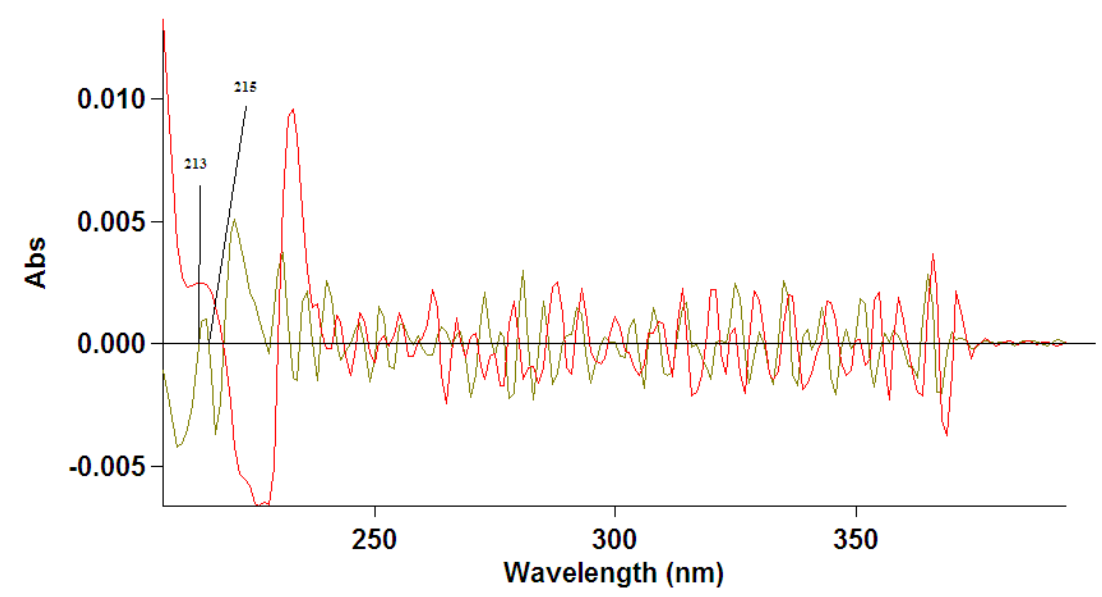

Fig. 7: Second order spectrum of metoprolol succinate and ramipril

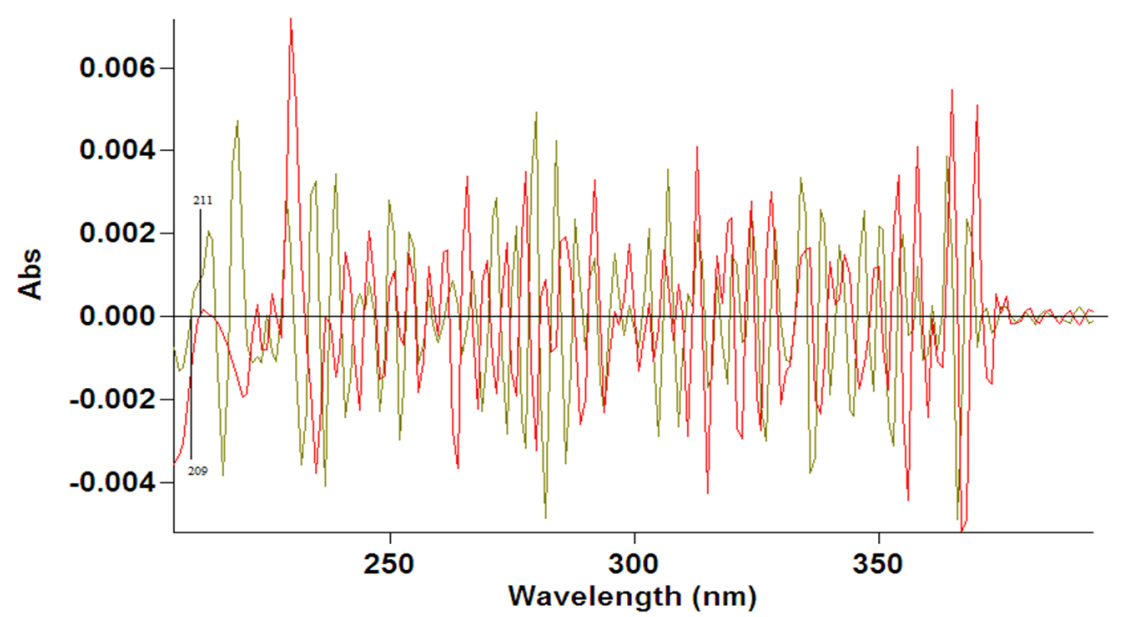

Fig. 8: Third order spectrum of metoprolol succinate and ramipril

\section{Linearity}

For the third order derivative method, $10-50 \mu \mathrm{g} / \mathrm{ml}$ of metoprolol succinate and $5-25 \mu \mathrm{g} / \mathrm{ml}$ of ramipril were scanned at the working wavelengths of $209 \mathrm{~nm}$ and $211 \mathrm{~nm}$ for metoprolol succinate and ramipril respectively. Calibration curves were constructed by plotting concentration against the absorbance values and correlation coefficients were calculated from the regression line equations.

\section{Accuracy}

To check the accuracy of the developed method, recovery studies were carried out by applying standard addition method. A known amount of standard metoprolol succinate and ramipril corresponding to 80,100 and $120 \%$ of the label claim was added to pre-analyzed sample of the tablet. The recovery studies were carried out at each level three times and the average amount was calculated. 


\section{Precision}

The precision of the developed method was carried out by intermediate precision. The intraday and interday precisions of the third order derivative method were determined by analyzing responses in triplicate on the same day and on 3 different days over a period of $1 \mathrm{w}$ of metoprolol succinate $(50 \mu \mathrm{g} / \mathrm{ml})$ and ramipril $(5 \mu \mathrm{g} / \mathrm{ml})$.

\section{Sensitivity}

The LOD and LOQ values were calculated from the linearity data using Microsoft excel 542010 version. Standard deviation of the analytical response and the slope of the calibration curve method was followed according to the equations, $\mathrm{LOD}=3.3 \sigma / \mathrm{S}$ and $\mathrm{LOQ}=10 \sigma / \mathrm{S}$, where $\sigma$ is the standard deviation of the sample and $S$ is the slope.

\section{Assay of commercial brand}

Twenty tablets of PROLOMET R 50 were taken, weighed and finely powdered. The weight equivalent to the labelled claim $(55 \mathrm{mg})$ was taken, $20 \mathrm{ml}$ of solvent (methanol and water $50: 50 \mathrm{v} / \mathrm{v}$ ) was added in a $100 \mathrm{ml}$ volumetric flask and sonicated in an ultrasonic bath for 15 min. This solution was then made upto $100 \mathrm{ml}$ using the same solvent, filtered through a $0.45 \mu \mathrm{m}$ filter and this filtrate was used to prepare sample solution $(55 \mu \mathrm{g} / \mathrm{ml})$. The mixture solution was scanned at the wavelengths of metoprolol succinate $(209 \mathrm{~nm})$ and ramipril $(211 \mathrm{~nm})$ using a UV-Visible spectrophotometer. These absorbance values were then substituted in the regression equations to calculate the concentration.

\section{RESULTS AND DISCUSSION}

Few chromatographic methods have been mentioned in the literature to date for the simultaneous estimation of metoprolol succinate and ramipril in their binary mixtures $[6,8,15]$. Also one spectrophotometric method, based on simultaneous equation has been reported for combination of metoprolol succinate, atorvastatin calcium and ramipril [16]. However, no spectrophotometric method has been reported for metoprolol succinate and ramipril in their fixed dose comination.

\section{Third order derivative method}

From the zero order overlain UV spectra of Metoprolol succinate $(30 \mu \mathrm{g} / \mathrm{ml})$ and ramipril $(15 \mu \mathrm{g} / \mathrm{ml})$, it was found that the spectra are overlapping each other, exhibiting the complexity in measuring these drugs by direct UV absorption method in a binary mixture. The UV derivative method has advantage that it removes the spectral interference from one of the two drugs while estimating the other drug at zero crossing point. The first order spectra did not show any zero crossing points (ZCP), while the second order spectra was not informative enough to carry out further experimentation. Hence in the present investigation, third order derivative spectrophotometric techniques was described. The third order spectrum showed zero crossing points (ZCP) at $211 \mathrm{~nm}$ for metoprolol succinate and $209 \mathrm{~nm}$ for ramipril. Hence working wave lengths of $209 \mathrm{~nm}$ for metoprolol succinate and 211 $\mathrm{nm}$ for ramipril were selected.

Table 1: Linearity characters of the developed method

\begin{tabular}{lll}
\hline Statistical parameters & Metoprolol succinate at 209 nm & Ramipril at 211 nm \\
\hline Linearity $(\mathrm{n}=5)$ & $10-50 \mu \mathrm{g} / \mathrm{ml}$ & $5-25 \mu \mathrm{g} / \mathrm{ml}$ \\
Correlation coefficient $\left(\mathrm{r}^{2}\right)$ & 0.998 & 0.997 \\
Regression equationy $=\mathrm{mx}+\mathrm{c}$ & $\mathrm{y}=0.021 \mathrm{x}+0.016$ & $\mathrm{y}=0.063 \mathrm{x}+0.769$ \\
Slope $(\mathrm{m})$ & 0.021 & 0.063 \\
Intercept $(\mathrm{c})$ & 0.016 & 0.769 \\
\hline
\end{tabular}

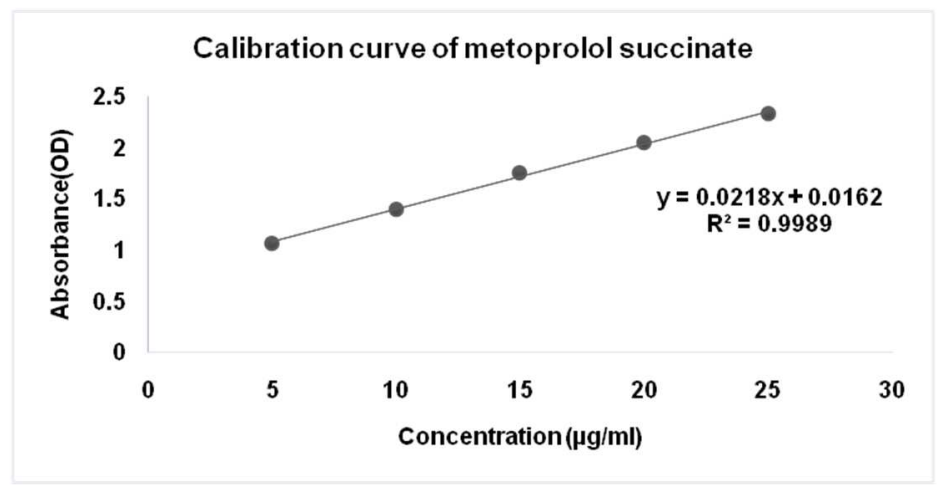

Fig. 9: Calibration curve of metoprolol succinate

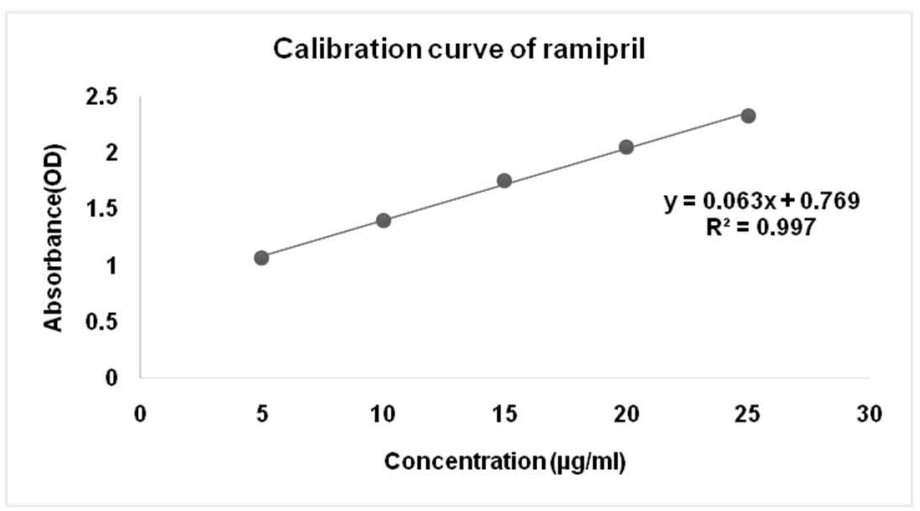

Fig. 10: Calibration curve of ramipril 
Table 2: Accuracy of the developed method

\begin{tabular}{|c|c|c|c|c|c|c|c|c|}
\hline \multirow[t]{2}{*}{$\begin{array}{l}\text { Spiked } \\
\text { level }\end{array}$} & \multicolumn{2}{|c|}{$\begin{array}{l}\text { Amount of sample taken } \\
\text { (mg) }\end{array}$} & \multicolumn{2}{|c|}{$\begin{array}{l}\text { Amount of pure drug added } \\
\text { (mg) }\end{array}$} & \multicolumn{2}{|l|}{$\begin{array}{l}\text { Amount recovered } \\
\left(\text { mean } \pm S D^{a}\right)\end{array}$} & \multicolumn{2}{|c|}{ \% Recovery $\pm S D^{a}$} \\
\hline & $\begin{array}{l}\text { Metoprolol } \\
\text { succinate }\end{array}$ & Ramipril & $\begin{array}{l}\text { Metoprolol } \\
\text { succinate }\end{array}$ & Ramipril & $\begin{array}{l}\text { Metoprolol } \\
\text { succinate }\end{array}$ & Ramipril & $\begin{array}{l}\text { Metoprolol } \\
\text { succinate }\end{array}$ & Ramipril \\
\hline $80 \%$ & 10 & 5 & 8 & 4 & $17.88 \pm 0.01$ & $8.96 \pm 0.01$ & $99.32 \pm 0.05$ & $99.57 \pm 0.17$ \\
\hline $100 \%$ & & & 10 & 5 & $20.1 \pm 0.01$ & $9.94 \pm 0.02$ & $100.53 \pm 0.07$ & $99.4 \pm 0.26$ \\
\hline $120 \%$ & & & 12 & 6 & $21.82 \pm 0.02$ & $10.98 \pm 0.03$ & $99.19 \pm 0.11$ & $99.81 \pm 0.27$ \\
\hline
\end{tabular}

aSD: Standard deviation $(n=3)$

Table 3: Precision data of the developed method

\begin{tabular}{|c|c|c|c|c|c|c|}
\hline \multirow[t]{2}{*}{ Parameter } & \multicolumn{3}{|c|}{ Metoprolol succinate $(50 \mu \mathrm{g} / \mathrm{ml})$} & \multicolumn{3}{|c|}{ Ramipril $(5 \mu \mathrm{g} / \mathrm{ml})$} \\
\hline & $n=3$ & mean $\pm S D^{a}$ & \% RSD ${ }^{b}$ & $n=3$ & mean $\pm S^{a}$ & $\% \mathrm{RSD}^{\mathrm{b}}$ \\
\hline \multirow[t]{3}{*}{ Intra-day } & 1.1152 & $1.1142 \pm 0.07$ & 0.1008 & 1.058 & $1.0623 \pm 0.08$ & 0.424 \\
\hline & 1.1130 & & & 1.067 & & \\
\hline & 1.1145 & & & 1.062 & & \\
\hline \multirow[t]{3}{*}{ Inter-day } & 1.1139 & $1.1139 \pm 0.09$ & 0.02693 & 1.062 & $1.0706 \pm 0.06$ & 0.754 \\
\hline & 1.1142 & & & 1.078 & & \\
\hline & 1.1136 & & & 1.072 & & \\
\hline
\end{tabular}

aSD: Standard deviation; b\% Relative standard deviation (R. SD) = (standard deviation $/$ mean $) \times 100 ;(n=3)$

Table 4: LOD and LOQ results of the developed method

\begin{tabular}{lll}
\hline Statistical parameter & Metoprolol succinate $(\boldsymbol{\mu g} / \mathbf{m l})$ & Ramipril $(\mu \mathrm{g} / \mathrm{ml})$ \\
\hline LOD & 3.18 & 1.56 \\
LOQ & 9.62 & 4.68 \\
\hline
\end{tabular}

Table 5: Assay of commercial brand

\begin{tabular}{|c|c|c|c|c|c|c|}
\hline Marketed formulation & Metoprolol succinate & & & Ramipril & & \\
\hline $\begin{array}{l}\text { PROLOMET } \\
\text { R } 50\end{array}$ & Labeled claim (mg) & $\begin{array}{l}\text { Amount recovered } \\
\text { (mg) }\end{array}$ & \% Recovery & $\begin{array}{l}\text { Labeled claim } \\
(\mathrm{mg})\end{array}$ & $\begin{array}{l}\text { Amount recovered } \\
(\mathrm{mg})\end{array}$ & \% Recovery \\
\hline (Sun Pharma) & 50 & 50.8 & $101.6 \%$ & 5 & 4.94 & $98.8 \%$ \\
\hline
\end{tabular}

\section{Validity of the method}

The linearity was found in the range of $10-50 \mu \mathrm{g} / \mathrm{ml}$ and $5-25 \mu \mathrm{g} / \mathrm{ml}$ for metoprolol succinate and ramipril. The calibration curves were shown in (fig. 9 and fig. 10) and the correlation coefficient $\left(r^{2}\right)$ value was found to be 0.998 and 0.997 , respectively. The $r^{2}$ values for both the drugs were found to be less than or equal to 1 . Hence the developed method was found to be linear. The \% recoveries were found to be $99.2 \%, 100.02 \%$ and $99.18 \%$ for metoprolol succinate and $99.5 \%, 99.4 \%$ and $99.81 \%$ for ramipril respectively. As the $\%$ recovery values were found to be between $98 \%-102 \%$, the developed method can be considered to be accurate. The intraday $\%$ RSD was found to be 0.1008 for metoprolol succinate and 0.424 for ramipril. The inter-day \% RSD was found to be 0.02693 for metoprolol succinate and 0.754 for ramipril. As the \% RSD values were found to be $2 \%$, the developed method can be considered to be precise. Detection limit was found to be $3.18 \mu \mathrm{g} / \mathrm{ml}$ for metoprolol succinate and $1.56 \mu \mathrm{g} / \mathrm{ml}$ for ramipril. Quantification limit was found to be $9.62 \mu \mathrm{g} / \mathrm{ml}$ for metoprolol succinate and $4.68 \mu \mathrm{g} / \mathrm{ml}$ for ramipril. The assay of the commercial brand was carried out and the recovery was found to $101.6 \%$ for metoprolol succinate and $98.8 \%$ for ramipril. The results of the validation are summarized in table 1 , $2,3,4$ and 5 .

\section{CONCLUSION}

A simple, precise, economical and sensitive UV derivative spectroscopic method was developed for the simultaneous estimation of metoprolol succinate and ramipril. The developed method was validated according to the ICH guidelines and was applied to the pharmaceutical dosage form. The result of the assay obtained was found to be within the acceptable limits. Hence, the developed method was said to be effective for routine analysis of metoprolol succinate and ramipril in tablet dosage form.

\section{ACKNOWLEDGMENT}

The authors are thankful to Dr. P. Udaya Shankar, Principal Maharajah's College of Pharmacy, Vizianagaram, Andhra Pradesh, for providing the necessary infrastructure and facility to carry out the research work.

\section{AUTHORS CONTRIBUTIONS}

All authors have equal contribution

\section{FUNDING}

Nil

\section{CONFLICTS OF INTERESTS}

Declared none

\section{REFERENCES}

1. Zhou MJ, Song L, Chaogang WU, Anping L, Haitao G, Guoqing Z. A new polymorphic form of metoprolol succinate. Pharm De Technol 2017;22:58-62.

2. Ripley TL, Joseph JS. $\beta$-blockers: a review of their pharmacological and physiological diversity in hypertension. Ann Pharmacother 2014;48:723-33.

3. Todd PA, Benfield P. Ramipril. Drugs 1990;39:110-35.

4. Theres HP, Wagner KD, Romberg D, Feig C, Strube S, Leiterer $\mathrm{KP}$, et al. Combined treatment with ramipril and metoprolol prevents changes in the creatine kinase isoenzyme system and improves hemodynamic function in rat hearts after myocardial infarction. Cardiovasc Drug Ther 2000;14:597-606.

5. Varaprasad C, Ramakrishna K. Gradient RP-HPLC method for simultaneous estimation of metoprolol, ramipril and atorvastatin in tablet dosage form. Rasayan J Chem 2015;8:404-10. 
6. Krishna KP, Prabhu PP, Chethan SH. Development and validation of new analytical methods for simultaneous estimation of ramipril and metoprolol succinate by HPLC method in combined tablet dosage form. Int I Pharm Chem Res 2017;3:746-55.

7. Phale MD, Hamrapurkar PD. A validated and simplified RPHPLC of metoprolol succinate from bulk drugs. Asian J Res Chem 2009;2:119-22.

8. Mohammad Y, Gowri SD. A new validated stability-indicating LC method for simultaneous determination of metoprolo succinate and ramipril in pharmaceutical marketed formulation. Der Pharm Lett 2015;7:82-92.

9. Raja KS, Makarand MD, Veera RT, Deepa K, Venugopala RD, Ivon EC. Simultaneous quantitative determination of metoprolol, atorvastatin and ramipril in capsules by a validated stabilityindicating RP-UPLC method. Sci Pharm 2010;78:821-34.

10. Moreshwar KN, Rajeshwar KV, Dinesh SM. Development and validation of a spectrophotometric method for determination of metoprolol succinate. Int I ChemTech Res 2009;1:1273-7.

11. Al-Majed AA, Belal F, Al-Warthan AA. Spectrophotometric determination of ramipril (a novel ACE inhibitor) in dosage forms. Spectrosc Lett 2001;34:211-20.
12. Patel HB, Patel BA, Parmar SJ. Development and validation of second order derivative spectrophotometric method for simultaneous estimation of atenolol and nifedipine in combined dosage form. Int J Pharm Sci Res 2013;4:3884-8.

13. Gadiya H, Maheshwari M, Dashora A. UV-analytical method development and validation for simultaneous estimation of dapoxetine hydrochloride and sildenafil citrate in tablet dosage form. Asian J Pharm Clin Res 2019;12:328-31.

14. ICH guideline, Q2 (R1). Validation of analytical procedures: Text and methodology, international conference on harmonization IFPMA, Geneva, Switzerland; 2005.

15. Sethy K, Rao JR, Rajeswari KR, Nagoji KEV. Validated HPTLC method for simultaneous estimation of metoprolol succinate and ramipril in bulk drug and marketed formulation. Bull Pure Appl Sci Chem 2019;38:150-7.

16. Sawant RL, Raskar MA, Sawant MR, Ahmed R, Pawar S. Simultaneous spectrophotometric estimation of metoprolol succinate, atorvastatin calcium and ramipril in the tablet dosage form. Anal Chem Lett 2012;2:320-6. 